Editorial

\title{
Terror in paris: the continuing problem of evil
}

Volume 4 Issue 2 - 2015

\section{Editorial}

I sit down to write this piece one day after the horrific events of November 132015 in Paris. Three teams of attackers heavily armed and wearing suicide vests, methodically and viciously attacked innocent people in six different locations. The death toll currently stands at 129 , with approximately 350 more wounded.

We are all familiar with those who break the law, who transgress against others, knowing full well that they are doing wrong. In instrumental evil, we find an agent who knowingly violates rules and norms to achieve some self-interested end. Importantly, this agent might have acted otherwise were he able to achieve his goals via more acceptable means. Although rationalizing his actions in various ways, perhaps arguing he had no choice but to act as he did or that the consequences of his actions were less serious than they appear, he understands that his actions are not justified by an objective good.

By contrast, the events in Paris confront us with evil of another sort. In ideologically-driven evil, the agent does not believe he is doing wrong. Rather, he believes his actions are justified by an objective good. Killing and maiming others is morally acceptable when viewed as promoting the goals and values of his family, his group, political party, country and/or religion. He is not burdened by guilt or regret because the victim is no longer viewed as human, as one of "us," but rather as an anonymous other devoid of any humanity. It is important to differentiate these two forms of evil if we are to fashion more effective means of responding to the challenge of evil. ${ }^{1}$ All too often, the public either demonizing those who commit such acts, interpreting them as motivated to perpetrate evil for its own sake rather than for reasons which are comprehensible however much we may rightly condemn them, or explains their acts by reference to a psychiatric disorder. Both of these perspectives fails to appreciate the complexity of the problem and obscures the combination of situational, historical, and motivational variable undergirding evil by blaming these actions on something other than the agent's choices. Without the freedom to choose otherwise, to refrain from such actions, we have no basis for attributing moral responsibility to perpetrators of terrorism, no way to distinguish evil from actions whose consequences are

\section{Ronald C Naso}

American Board and Academy of Psychoanalysis, USA

Correspondence: Ronald C Naso,American Board and Academy of Psychoanalysis, 2777 Summer Street, Suite 504B, Stamford, CT 06905, USA, Email rcnphd@gmail.com

Received: November II, 2015 | Published: November 17, 2015

unfortunate, but inadvertent or unintended. Only when we understand the horrific actions of terrorists as serving perverse but thoroughly human ends can we begin to fashion strategies that are responsive to evil's ever-changing forms.

\section{Acknowledgments}

None.

\section{Conflicts of interest}

Author declares there are no conflicts of interest.

\section{Funding}

None.

\section{References}

1. Naso RC, Mills J. Humanizing Evil: Psychoanalytic, Philosophical and Clinical Perspectives. Routledge, UK, forthcoming. 2016. 